\title{
Seed germination at different stratification temperatures and development of Phytelephas macrocarpa Ruiz \& Pavón seedlings ${ }^{1}$
}

\author{
Sidney Alberto do Nascimento Ferreira ${ }^{2 *}$, Daniel Felipe de Oliveira Gentil ${ }^{3}$
}

\begin{abstract}
Phytelephas macrocarpa (ivory palm) is an Amazonian palm vulnerable to exploitation pressure, as its seeds are widely used in regional handicrafts. The aims of this study were to evaluate the effectiveness of different stratification temperatures in overcoming seed dormancy and to analyze the seedling development stages of this species. In germination under stratification, the seeds were placed in plastic bags containing moistened vermiculite, and maintained at the constant temperatures of $25,30,35$ and $40{ }^{\circ} \mathrm{C}$, and an alternating temperature from 26 to $40{ }^{\circ} \mathrm{C}$. In the study about the development of seedlings, seeds were sown in vermiculite under plastic cover (growing house), and the evolution of the seedling was evaluated, from the formation of germinative button to the complete blade expansion of the first eophyll. Stratification at alternating temperatures $\left(26\right.$ to $40{ }^{\circ} \mathrm{C}$ ) helped overcoming seed dormancy. Stratification at $25{ }^{\circ} \mathrm{C}$ kept the seed viability for nine months. Germination, characterized by the formation of the germinative button took an average of $114 \pm 24$ days, and the seedling development until the first extended eophyll lasted $244 \pm 57$ days.
\end{abstract}

Index terms: Arecaceae, vegetable ivory, dormancy, seedling stages.

\section{Germinação de sementes em diferentes temperaturas de estratificação e desenvolvimento pós-seminal de Phytelephas macrocarpa Ruiz \& Pavón}

\begin{abstract}
RESUMO - Phytelephas macrocarpa (jarina) é uma palmeira amazônica vulnerável à pressão extrativista, em virtude de suas sementes serem bastante utilizadas no artesanato regional. Os objetivos deste trabalho foram avaliar a eficiência de diferentes temperaturas de estratificação na superação da dormência das sementes e analisar os estádios de desenvolvimento da plântula dessa espécie. Na germinação sob estratificação, as sementes foram acondicionadas em sacos plásticos, contendo vermiculita umedecida, e mantidas nas temperaturas constantes de $25,30,35$ e $40{ }^{\circ} \mathrm{C}$, e alternada de 26 a $40{ }^{\circ} \mathrm{C}$. No estudo sobre o desenvolvimento da plântula, as sementes foram semeadas em vermiculita, sob estufim, e avaliada a evolução da plântula, desde a formação do botão germinativo até a completa expansão laminar do primeiro eofilo. A estratificação em temperatura alternada $\left(26\right.$ a $\left.40{ }^{\circ} \mathrm{C}\right)$ favoreceu a superação da dormência das sementes. A estratificação a $25^{\circ} \mathrm{C}$ conservou a viabilidade das sementes por nove meses. A germinação, caracterizada pela formação do botão germinativo, levou em média $114 \pm 24$ dias, e o desenvolvimento da plântula até o primeiro eofilo expandido durou $244 \pm 57$ dias.
\end{abstract}

Termos para indexação: Arecaceae, jarina, dormência, estádios da plântula.

\section{Introduction}

Phytelephas macrocarpa Ruiz \& Pavón (Arecaceae), known as ivory palm, is a species occurring in understories of the dry land rainforest, in plains from old floods or inundated plains of rivers in the Southeastern Amazon, in a region reaching territories from Peru, Brazil and Bolivia (Henderson et al., 1995). It is a palm tree with different uses, particularly the leaves, used to cover constructions, create baskets (utilities

\footnotetext{
${ }^{1}$ Submitted on 07/08/2016. Accepted for publication on 01/11/2017. ${ }^{2}$ Instituto Nacional de Pesquisas da Amazônia, Caixa Postal 2223, 69080971- Manaus, AM, Brasil.
}

and handicrafts) and ropes (fibers), and the seeds, whose liquid or jelly endosperm is appreciated as human and animal food; when solidified, it is used as a substitute raw material for animal ivory, in the creation of jewelry and handicrafts (Costa et al., 2008). Generally speaking, the exploitation of the species is extractive, since there is no cultivation for industrial purposes in Brazil, even if they exist in Peru. In a study conducted in Ecuador with a similar species, Brokamp et al. (2014) highlighted that the exploitation of $P$. aequatorialis

${ }^{3}$ Universidade Federal do Amazonas, Faculdade de Ciências Agrárias, $69077-$ 000- Manaus, AM, Brasil.

*Corresponding author< sanf@inpa.gov.br> 
leaves and seeds must be carefully conceived, avoiding unsustainable harvest practices and population decrease.

P. macrocarpa is worth attention, due to some aspects that may negatively affect its structure and population dynamic, related to: (a) seed production - the excessive extractive harvesting; the predation by wild animals; the existence of dormancy mechanisms (Barfod, 1991; Costa et al., 2008); (b) the species maintenance - reproduction only by seeds; the slow growth, whose reproductive stage occurs almost every ten years; the dioeciuos sexual system (Barfod, 1991); and (c) the ecosystem level - the fragmentation and loss of the natural habitat (Carvalho et al., 2010). Therefore, understanding dormancy mechanisms may help both managing and cultivating P. macrocarpa. According to Baskin and Baskin (2014b), most palm trees present morpho-physiological dormancy, since it takes more than 30 days to germinate and they have sub-developed embryos.

In the morpho-physiological dormancy, two events must precede seed germination; the embryo must complete its development and its physiological dormancy must be overcome (Baskin and Baskin, 2014a). In some species, the development of the embryo and the overcoming of the physiological dormancy are promoted by the same environmental condition, whereas in others, they require different conditions, such as stratification: hot, cold, hot-cold, cold-hot and cold-hot-cold (Baskin and Baskin, 2014a).

Most palm tree seeds are thermophilic, that is, they need high temperatures $\left(30\right.$ to $\left.40^{\circ} \mathrm{C}\right)$ in order to overcome dormancy (Orozco-Segovia et al., 2003). However, germination under high and constant temperature is not always adequate (Schlindwein et al., 2013), but it is harmful for some species that require high temperature followed by a relatively low temperature (Orozco-Segovia et al., 2003; Pérez et al., 2008; Pimenta et al., 2010).

Knowing the development of seedlings may subsidize botanical, ecological, agronomical and silvicultural studies, helping the identification of species, as in recognizing individuals from the natural regeneration (Bernacci et al., 2008; Carvalho et al., 2010; Portela and Santos, 2011), the interpretation of germination and seed vigor tests and the production of seedlings (Henderson, 2006; Brasil, 2009; Queiroz and Bianco, 2009). In palm trees, three types of germination (adjacent ligular, remote ligular and remote tubular) were the basis of discussions about seedlings. Other combined characteristics would be equally adequate to the morphological description of germination, such as orientation of the primary root, ligule length, number of cataphylls and eophyll plication (Henderson, 2006).

Based on the above considerations, the aims of this work were to evaluate the effectiveness of different stratification temperatures in overcoming seed dormancy and to analyze the development stages of P. macrocarpa seedlings.

\section{Material and Methods}

Two recently dispersed $P$. macrocarpa seed lots (diaspores) were collected in the state of Acre, Northern region of Brazil. Lot 1 was composed by seeds from 12 plants, obtained in the city of Brasiléia (10 $50^{\prime} 38^{\prime \prime}$; $\left.69^{\circ} 17^{\prime} 22^{\prime \prime} \mathrm{W}\right)$. Lot 2 came from four plants, established in the city of Rio Branco ( $9^{\circ} 56^{\prime} 28.23$ "S; $68^{\circ} 0^{\prime} 9.74$ ' W). After harvesting, seeds were washed under running water and dried in the shadow for 24 hours. Lots were forwarded to Manaus, by plane, wrapped in plastic bags.

\section{Germination in different stratification temperatures}

Samples of 20 seeds were randomly taken from lot 1 and separately placed in plastic bags $(24 \times 38 \mathrm{~cm})$, containing fine texture vermiculite (twice the seed volume), dampened with water, the equivalent of $60 \%$ of the dry vermiculite mass. After that, the bags were kept in chambers with different constant $(25$, 30,35 and $40{ }^{\circ} \mathrm{C}$ ) and alternating $\left(26\right.$ to $\left.40{ }^{\circ} \mathrm{C}\right)$ temperatures. In the alternate condition, a timer set the temperature of $40^{\circ} \mathrm{C}$ at $9 \mathrm{AM}$ and turned it off at $3 \mathrm{PM}$; in the meantime, in 24-hour cycles, the internal temperature of the chamber was reduced, reaching the minimum average of $26{ }^{\circ} \mathrm{C}$. The experimental design was completely randomized, with five treatments (temperatures) and three replications (samples).

The formation of the germinative button was followed every 15 days, for nine months. Count values were transformed into percentages and, starting from them, the germination speed index and average time were calculated, as described in Ranal and Santana (2006). When closing the experiment, except for the $25^{\circ} \mathrm{C}$ treatment, whose seeds were transferred to alternating temperature $\left(26\right.$ to $\left.40{ }^{\circ} \mathrm{C}\right)$, the remaining seeds (not germinated) from the other experiments were submitted to cutting test (Brasil, 2009) in order to individually analyze their condition (dormant or dead), expressing the results in percentage.

Data in percentage were transformed into an arc sine square root of $x+1$; the averages of the original values were presented in the results. After the analysis of variance, averages were compared by Tukey's test, at 5\% probability level, using the Assistat 7.7 beta program (Silva and Azevedo, 2016).

\section{Post-seminal development}

Seeds came from the mixture of 50 units from each lot were planted in plastic boxes $(60 \times 50 \times 30 \mathrm{~cm})$, drained, and filled with medium texture vermiculite until $2 / 3$ of their height $(20 \mathrm{~cm})$. Each box was covered with agricultural film (150 
micron thickness), in order to create a growing house, similar to the one adopted by Ferreira et al. (2010), in the germination Astrocaryum aculeatum G. Mey. The boxes were kept in a natural environment, under a canvas vivarium (35'29.66"S; $59^{\circ} 59^{\prime} 34.65^{\prime \prime} \mathrm{W}$ ) with $50 \%$ shadowing, for 345 days. After the initial wetting of the substrate, irrigation was performed when needed, trying to avoid excess moisture.

After sowing, every 15 days germination (formation of the germinative button) and seedling development (lengthening of the hyperphyll; swelling of the cotiledonary sheath, primary, adventitious and secondary root emission; cataphylls emission; emission of the first eophyll; and complete expansion of the first eophyll). The morphological descriptions of the seedlings were based on the terminology used by Henderson (2006). For that, seedlings in different stages were fixed in FAA 50 (formaldehyde, acetic acid and alcohol 50\%) and, later, preserved in alcohol 70\%. Box plots were created for the time of occurrence of the stages: (a) germinative button; (b) emission of the primary root and (c) complete expansion of the first eophyll, showing median, average, quartiles and extreme and discrepant values.

\section{Results and Discussion}

\section{Germination in different stratification temperatures}

P. macrocarpa seeds presented higher germination (88\%) under alternating temperature $\left(26\right.$ to $40{ }^{\circ} \mathrm{C}$ ) (Table 1). In the constant temperatures of 30,35 and $40{ }^{\circ} \mathrm{C}$ there was a significant germination reduction, whereas at $25{ }^{\circ} \mathrm{C}$ germination did not occur. However, after transferring seeds from that treatment to the alternating treatment $\left(26\right.$ to $\left.40{ }^{\circ} \mathrm{C}\right)$, it resulted in $90 \%$ germination, in an additional period of 120 days. In Mauritia flexuosa L. seeds, Silva et al. (2014) verified a similar behavior, since germination passed from $0 \%$ (incubation at $15{ }^{\circ} \mathrm{C}$ ) to $65 \%$, after the subsequent exposure to the constant temperature of $30^{\circ} \mathrm{C}$.

The germination speed index had a similar behavior to the germination (Table 1), with the highest verified value $\left(0.812 \%\right.$. day $\left.^{-1}\right)$ in the alternating temperature, even if it did not statistically differ from what was observed at the constant temperature of $35^{\circ} \mathrm{C}\left(0.546 \%\right.$ day $\left.^{-1}\right)$. The average germination time did not present any significant difference between the treatments, with a general average of 146 days, even if a lower value (126 days) was observed in the alternating temperature.

In the evaluation of the remaining seeds (Table 1), the lowest percentage of dormant seeds $(3 \%)$ was verified for the alternating temperature, which significantly differed from the others. Among the constant temperatures, the higher percentages of dormant seeds were reached at $30{ }^{\circ} \mathrm{C}(70 \%)$ and $25^{\circ} \mathrm{C}$ (about $90 \%$, based on the germination obtained after transferring the seeds to the alternating temperature). The percentage of dead seeds did not highlight any statistical difference between the treatments.

The different stratification conditions resulted in different behaviors as for the beginning of germination and distribution of this process in time (Figure 1): at 35 and 26 to $40{ }^{\circ} \mathrm{C}$ the beginning was between 16 and 30 days; at the temperature of $30{ }^{\circ} \mathrm{C}$ it started between 31 and 45 days; and at $40{ }^{\circ} \mathrm{C}$ between 76 and 90 days. On the $135^{\text {th }}$ day of stratification (half of the observation period), $60 \%$ of the seeds at the alternating temperature had germinated, whereas the verified percentages at the other temperatures were lower: $13.3 \%$ at $30{ }^{\circ} \mathrm{C} ; 31.7 \%$ at $35^{\circ} \mathrm{C}$; and $18.3 \%$ at $40{ }^{\circ} \mathrm{C}$.

The stratification temperatures also provided a different initial development of the seedlings: at the constant temperature of $30{ }^{\circ} \mathrm{C}$ and at the alternating one from 26 to $40{ }^{\circ} \mathrm{C}$, the hyperphyll was long, whereas at constant 35 and

Table 1. Germination, germination speed index (GSI), germination average time (GAT), dormant and dead seeds of Phytelephas macrocarpa Ruiz \& Pavón submitted to different stratification temperatures. ${ }^{1}$

\begin{tabular}{cccccc}
\hline $\begin{array}{c}\text { Temperature } \\
\left({ }^{\circ} \mathrm{C}\right)\end{array}$ & $\begin{array}{c}\text { Germination } \\
(\%)\end{array}$ & $\begin{array}{c}\text { GSI } \\
\left(\% . \text { day }^{-1}\right)\end{array}$ & $\begin{array}{c}\text { GAT } \\
(\text { days })\end{array}$ & $\begin{array}{c}\text { Dormant seeds } \\
(\%)\end{array}$ & $\begin{array}{c}\text { Dead seeds } \\
(\%)\end{array}$ \\
\hline $25^{2}$ & $0.0 \mathrm{~d}$ & - & - & - & - \\
30 & $26.7 \mathrm{c}$ & $0.228 \mathrm{~b}$ & $159.8 \mathrm{a}$ & $70.0 \mathrm{a}$ & $3.3 \mathrm{a}$ \\
35 & $55.0 \mathrm{~b}$ & $0.546 \mathrm{ab}$ & $141.1 \mathrm{a}$ & $35.0 \mathrm{~b}$ & $10.0 \mathrm{a}$ \\
40 & $43.3 \mathrm{bc}$ & $0.317 \mathrm{~b}$ & $155.9 \mathrm{a}$ & $45.0 \mathrm{~b}$ & $11.7 \mathrm{a}$ \\
26 to 40 & $88.3 \mathrm{a}$ & $0.812 \mathrm{a}$ & $125.9 \mathrm{a}$ & $3.3 \mathrm{c}$ & $8.3 \mathrm{a}$ \\
\hline CV $(\%)$ & 13.4 & 32.4 & 18.4 & 10.5 & 40.9 \\
F Test & $60.7 * *$ & $8.6 * *$ & $1.6^{\mathrm{ns}}$ & $73.8^{* *}$ & $0.84^{\mathrm{ns}}$ \\
\hline
\end{tabular}

1 - Averages followed by the same letter in the columns do not significantly differ among themselves by Tukey's test at $5 \%$.

2 - The GSI and GAT were not calculated, due to the non occurrence of germination; cutting test was also not performed (dormant and dead seeds), since seeds were transferred to the alternating temperature $\left(26\right.$ to $\left.40{ }^{\circ} \mathrm{C}\right)$.

** - Significant at $1 \%$ probability by $\mathrm{F}$ test; $\mathrm{ns}$ - not significant at 5 and $1 \%$ probability by $\mathrm{F}$ test. 


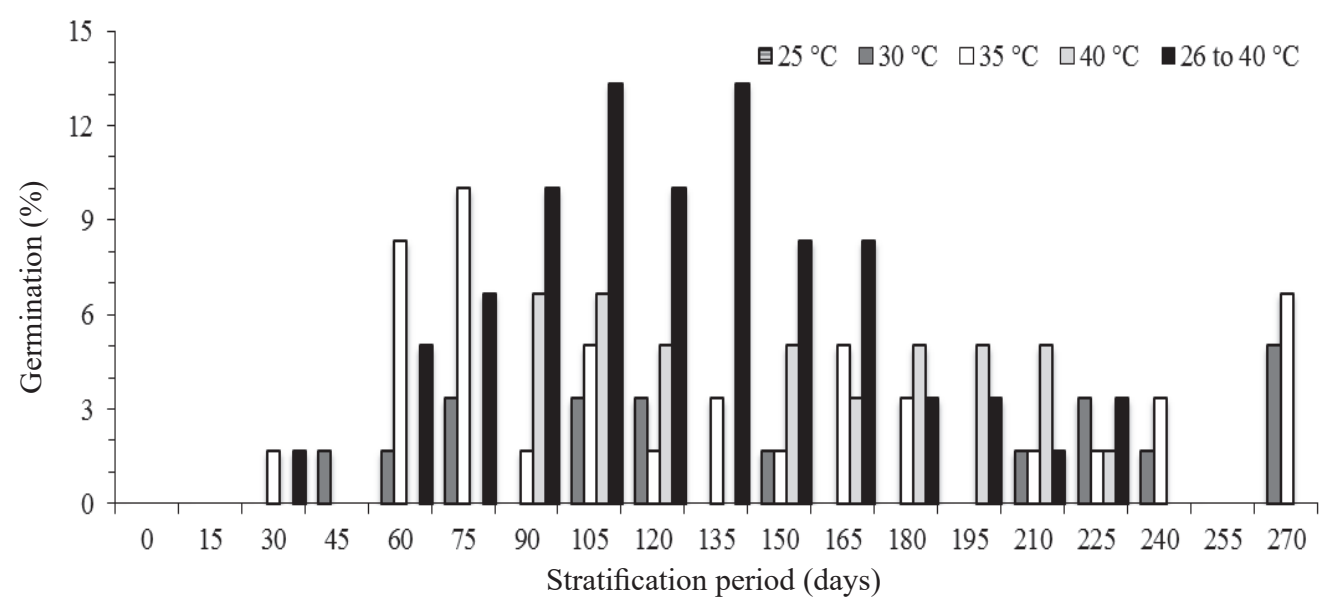

Figure 1. Fortnightly germination of Phytelephas macrocarpa Ruiz \& Pavón seeds, submitted to different stratification temperatures, for nine months.

$40{ }^{\circ} \mathrm{C}$ they were short, with apparent abnormality. Pérez et al. (2008), while observing that Pritchardia remota (Kuntze) Becc. seeds, kept at $35{ }^{\circ} \mathrm{C}$, produced less vigorous plants, recommended trimming right after germination. As for $P$. macrocarpa, regardless of the temperature, seedlings should be transferred to a vivarium until the hyperphyll stage in development, in order to avoid the formation of twisted seedlings, due to the stratification packaging (plastic bag).

The constant temperatures of $25,30,35$ and $40{ }^{\circ} \mathrm{C}$ did not provide high germination percentages in $P$. macrocarpa seeds (Table 1; Figure 1). In Bactris maraja Mart., constant temperatures of $20,25,30$ and $35^{\circ} \mathrm{C}$ were also not favorable for germination (Rodrigues et al., 2014). In palm trees, high temperatures $\left(30\right.$ to $\left.40^{\circ} \mathrm{C}\right)$ may be beneficial only when used as short pre-treatments to relieve dormancy, but seeds need to get back to lower temperatures for the seedling growth (Orozco-Segovia et al., 2003; Pérez et al., 2008; Pimenta et al., 2010). This was observed in Butia odorata (Barb. Rodr.) Noblick, at $40{ }^{\circ} \mathrm{C}$ for 21 days and, after that, at a constant temperature of $30{ }^{\circ} \mathrm{C}$ (Schlindwein et al., 2013); and in the interspecies hybrid Elaeis oleifera (Kunth) Cortés x E. guineensis Jacq., at $39 \pm 1{ }^{\circ} \mathrm{C}$ for 75 days and, after that, at a temperature between 27 and $30^{\circ} \mathrm{C}$ (Lima et al., 2014).

The germination of $P$. macrocarpa was helped by the stratification at alternating temperature $\left(26\right.$ to $\left.40{ }^{\circ} \mathrm{C}\right)$ (Table 1 ; Figure 1), similarly to what was observed in $B$. maraja seeds at 26 to $40{ }^{\circ} \mathrm{C}$ (Rodrigues et al., 2014). Alternating temperatures are generally less favorable than the constant ones for the germination of seeds from lots of palm trees; the difference between high and low temperatures must be equal or higher than $10{ }^{\circ} \mathrm{C}$ (Baskin and Baskin, 2014a). In Astrocaryum aculeatum G. Mey, Ferreira et al. (2010) verified that planting in growing houses with wider heat amplitudes $\left(13-14{ }^{\circ} \mathrm{C}\right)$ and higher average maximum temperatures $\left(38-39{ }^{\circ} \mathrm{C}\right.$ ), helped the germination process. Anyway, high temperatures seem to have a regulatory role in the process of overcoming dormancy, confirming what was said by Orozco-Segovia et al. (2003) and Schlindwein et al. (2013).

The positive response to stratification at alternating temperatures represents a symptom of the morphophysiological dormancy in P. macrocarpa seeds. However, other studies must develop the investigation to confirm this kind of dormancy in seeds from the species.

\section{Post-seminal development}

The first visible sign of germination was the protrusion of the hypocotyl-radicle axis, which occurred on the bulged side of the diaspore, next to the hilum, due to the initial growth of the hyperphyll. With that, the discoid operculum was broken, made of part of the endocarp, opercular tegument and micropylar endosperm (Figure 2A).

Subsequently, the germinative button was formed, $114 \pm$ 24 days after planting (Figure 3), characterized by the conicrounded shape, colored in beige and with a smooth surface (Figure 2B). At this stage, germination was $65 \%$. Of the remaining seeds (not germinated), 345 days after planting, $18 \%$ remained dormant and $17 \%$ were dead.

The hyperphyll presented positive geotropism and stretched (Figures 2C-D), being able to reach variable lengths (Figures 2D-I), internally leading in its edges (cotiledonary sheath) the leaf primordia and radicle. Its shape is cylindrical, with furrowed surface and brown color, except for the beige basal region, which has cracks, exposing the internal white part. At the end of the stretching, there was a swelling of the cotiledonary sheath.

The primary root emerged from the cotiledonary sheath 


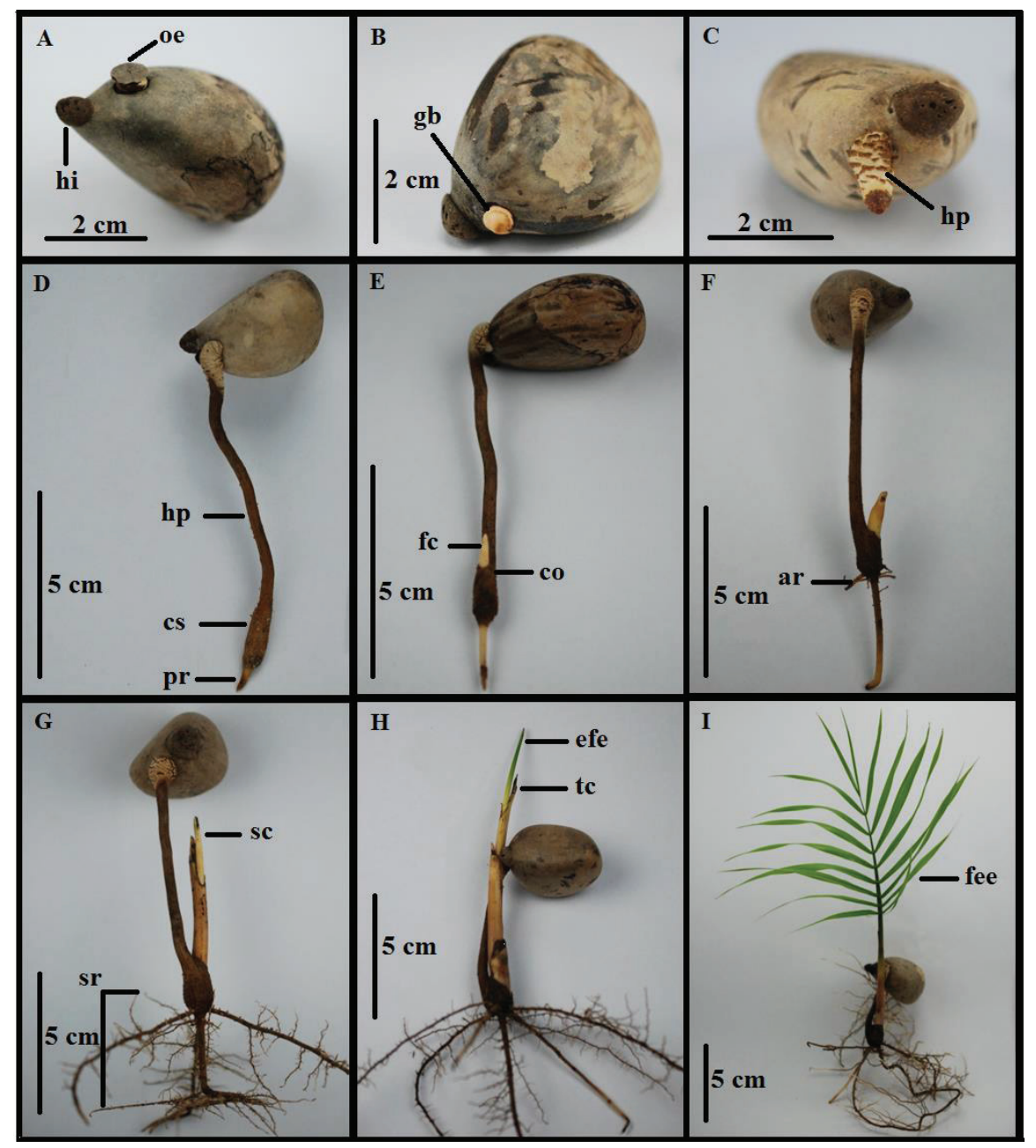

Figure 2. Development of Phytelephas macrocarpa Ruiz \& Pavón seedlings. A - protrusion of the embryonic axis, with detached operculum; B - formation of the germinative button; C - initial development of the hyperphyll; D developed hyperphyll, with swelling of the cotiledonary sheath and emission of the primary root; E - emission of the first cataphyll; F - emission of adventitious roots; $\mathrm{G}$ - emission of the second cataphyll; $\mathrm{H}$ - third cataphyll and emission of the first eophyll; I - first expanded eophyll. Caption: ar - adventitious root; co - coleoptile (ligule); cs - cotiledonary sheath; efe - emission of the first eophyll; fc - first cataphyll; fee - first expanded eophyll; gb germinative button; hi - hilum; hp - hyperphyll; oe - opercular endocarp; pr - primary root; sc - second cataphyll; sr - secondary root; tc - third cataphyll.

edge (Figure 2D), on day $149 \pm 25$ after planting (Figure 3). The first adventitious roots emerged above the primary root (Figure $2 \mathrm{~F}$ ). The secondary roots appeared initially in the primary root and, later, in the adventitious ones (Figure 2G-I). The primary root is persistent, similarly to what was verified in Phytelephas seemannii O. F. Cook and Phytelephas tenuicaulis (Barfod) A. J. Hend (Henderson, 2006).

The emergence of the first cataphyll occurred in the upper part of the cotiledonary sheath (Figure 2E), at the same time as the coleoptile formation, which involves it. The lengthening of the hyperphyll and the formation of the coleoptile (ligule) are remarkable characteristics in the remote ligular germination (Barfod, 1991).

Remote germination may have an adapting meaning, where the lengthening of the hyperphyll helps the development of the seedling at some distance from the seed, protecting it from events such as destruction by faire in dry environments, for example (Orozco-Segovia et al., 2003). Bernacci et al. (2008) suggest that, in Syagrus romanzoffiana (Cham.) Glossman, this kind of germination may help surviving in dry areas, allowing higher ecologic plasticity. However, the protection against desiccation must not be considered as the 


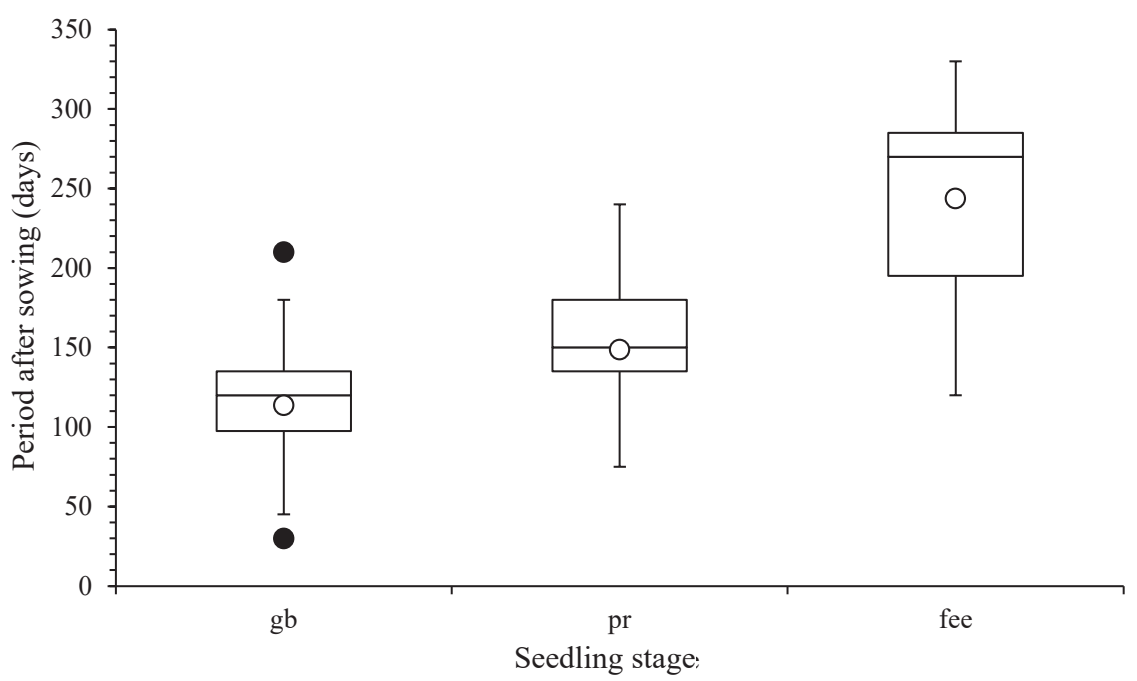

Figure 3. Box plot of the time of occurrence variation of different development stages of Phytelephas macrocarpa Ruiz \& Pavón seedlings, in growing house: gb - formation of the germinative button; pr - formation of the primary root; fee - first expanded eophyll; empty circle $=$ average time; full circle $=$ discrepant value.

only reason for the existence of remote germination, since the burial of the seedling may grant its survival, in case the seed was predated (Pinheiro, 2002).

The second cataphyll of the $P$. macrocarpa seedling emerged laterally in the distal part of the first one, presenting acute apex and variable length (Figures $2 \mathrm{G}-\mathrm{H}$ ). A possible third cataphyll may occur (Figure 2H). Barfod (1991) reports that there are two cataphylls in Phytelephas seedlings, but three in P. seemannii. According to Henderson (2006), P. seemannii and $P$. tenuicaulis seedlings naturally have three cataphylls.

The first eophyll emerged laterally in the distal part of the last cataphyll (Figure 2H). The complete expansion of the leaf blade (Figure 2I) occurred on day $244 \pm 57$ after planting (Figure 3). The eophyll is pin-settled, similarly to those of $P$. seemannii and P. tenuicaulis seedlings (Henderson, 2006). Not uncommonly, the first eophyll may present reduced or rudimentary leaf blade.

Planting in growing house condition reduced the average formation time of the germinative button (114 days) in relation to the average of treatments with stratification at different temperatures (146 days).

\section{Conclusions}

Stratification at alternating temperature $\left(26\right.$ to $\left.40{ }^{\circ} \mathrm{C}\right)$ helped overcoming dormancy in Phytelephas macrocarpa seeds. Stratification at $25^{\circ} \mathrm{C}$ maintained the viability of seeds for nine months. Germination, characterized by the formation of the germinative button, took $114 \pm 24$ days on an average, and the seedling development up to the first expanded eophyll lasted $244 \pm 57$ days.

\section{Acknowledgments}

To Dr. Evandro José Linhares Ferreira (INPA - Núcleo do Acre) and to Davi Pinheiro de Souza Sopchaki, Master's Degree and Forest Engineer, for collecting and providing the seeds used in the present study.

\section{References}

BARFOD, A.S. A monographic study of the subfamily Phytelephantoideae (Arecaceae). Opera Botanica, v.105, p.5-73, 1991. https://www.researchgate.net/publication/256402051_A_ monographic_study_of_the_subfamily_Phytelephantoideae_ Arecaceae

BASKIN, C.C.; BASKIN, J.M. Seeds: ecology, biogeography, and evolution of dormancy and germination. 2ed. San Diego: Elsevier, 2014a. 1586p.

BASKIN, J.M .; BASKIN, C.C. What kind of seed dormancy might palms have? Seed Science Research, v.24, n.1, p.17-22, 2014b. http:// journals.cambridge.org/action/displayFulltext?type $=1 \&$ fid $=9174543 \&$ jid $=$ SSR \&volumeId $=24 \&$ issueId $=01 \&$ aid $=9174540$

BERNACCI, L.C.; MARTINS, F.R.; SANTOS, F.A.M. Estrutura de estádios ontogenéticos em população nativa da palmeira Syagrus romanzoffiana (Cham.) Glassman (Arecaceae). Acta Botânica Brasílica, v.22, n.1, p.119-130, 2008. http://www.scielo.br/pdf/abb/ v22n1/a14v22n1.pdf

BRASIL. Ministério da Agricultura, Pecuária e Abastecimento. Regras para análise de sementes. Ministério da Agricultura, Pecuária e Abastecimento. Secretaria de Defesa Agropecuária. Brasília, DF: MAPA/ACS, 2009. 395p. http://www.agricultura.gov.br/arq_editor/ file/2946_regras_analise_sementes.pdf 
BROKAMP, G.; PEDERSEN, H.B.; MONTÚFAR, R.; JÁCOME, J.; WEIGEND, M.; BALSLEV, H. Productivity and management of Phytelephas aequatorialis (Arecaceae) in Ecuador. Annals of Applied Biology, v.164, n.2, p.257-269, 2014. http://onlinelibrary. wiley.com/doi/10.1111/aab.12098/pdf

CARVALHO, A.L.; FERREIRA, E.J.L.; LIMA, J.M.T. Comparações florísticas e estruturais entre comunidades de palmeiras em fragmentos de floresta primária e secundária da Área de Proteção Ambiental Raimundo Irineu Serra - Rio Branco, Acre, Brasil. Acta Amazonica, v.40, n.4, p. 657-666, 2010. http://www.scielo.br/pdf/aa/ v40n4/v40n4a04.pdf

COSTA, M.L.; HOHN, H.; RODRIGUES, S.F.S. Jarina: o marfim da Amazônia. Belém: Paka-Tatu, 2008. 156p.

FERREIRA, S. A. N.; CASTRO, A. F.; GENTIL, D.F.O. Emergência de plântulas de tucumã em função do pré-tratamento das sementes e da condição de semeadura. Revista Brasileira de Fruticultura, v.32, n.4, p.1189-1195, 2010. http://www.scielo.br/pdf/rbf/v32n4/ aop15410.pdf

HENDERSON, A.; GALEANO, G.; BERNAL, R. Field guide to the palms of the Americas. Princeton: Princeton University Press, 1995. 352p.

HENDERSON, F.M. Morphology and anatomy of palm seedlings. The Botanical Review, v.72, n.4, p.273-329, 2006. http://link.springer. com/article/10.1663\%2F0006-8101\%282006\%2972[273\%3AMAA OPS]2.0.CO $\% 3 \mathrm{~B} 2 \# /$ page-1

LIMA, W.A.A.; LOPES, L.; GREEN, M.; CUNHA, R.N.V.; ABREU, S.C.; CYSNE, A.Q. Heat treatment and germination of seeds of interspecific hybrid between American oil palm (Elaeis oleifera (H.B.K) Cortes) and African oil palm (Elaeis guineensis Jacq.). Journal of Seed Science, v.36, n.4, p.451-457, 2014. http:// www.scielo.br/pdf/jss/v36n4/a10v36n4.pdf

OROZCO-SEGOVIA, A.; BATIS, A.I.; ROJAS-ARÉCHIGA, M.; MENDOZA, A. Seed biology of palms: a review. Palms, v.47, n.2, p.79-94, 2003. http://www.palms.org/palmsjournal/2003/ vol47n2p79-94.pdf

PÉREZ, H.E.; CRILEY, R.A.; BASKIN, C.C. Promoting germination in dormant seeds of Pritchardia remota (Kuntze) Beck an endangered palm endemic to Hawaii. Natural Areas Journal, v.28, n.3, p.250-260, 2008. http://www.bioone.org/doi/pdf/10.3375/0885$8608 \% 282008 \% 2928[251 \% 3$ APGIDSO]2.0.CO\%3B2

PIMENTA, R.S.; LUZ, P.B.; PIVETTA, K.F.L.; CASTRO, A.; PIZETTA, P.U.C. Efeito da maturação e temperatura na germinação de sementes de Phoenix canariensis Hort. ex Chabaud - Arecaceae. Revista Árvore, v.34, n.1, p.31-38, 2010. http://www.scielo.br/pdf/ rarv/v34n1/v34n1a04.pdf
PINHEIRO, C.U.B. Germination strategies of palms: the case of Schippia concolor Burret in Belize. Brittonia, v.53, n.4, p.519-527, 2002. http://download.springer.com/static/pdf/106/ art $\% 253 \mathrm{~A} 10.1007 \% 252 \mathrm{FBF} 02809652$.pdf? originUrl $=\mathrm{ht}$ tp $\% 3 \mathrm{~A} \% 2 \mathrm{~F} \% 2 \mathrm{Flink}$.springer.com $\% 2 \mathrm{Farticle} \% 2 \mathrm{~F} 10.1007 \% 2 \mathrm{FB}-$ F02809652\& token $2=\exp =1467403534 \sim$ acl $=\% 2 \mathrm{Fstatic} \% 2 \mathrm{Fp}$ df\%2F 106\%2Fart\%25253A 10.1007\%25252FBF02809652. pdf\%3ForiginUr1\%3Dhttp $\% 253 \mathrm{~A} \% 252 \mathrm{~F} \% 252 \mathrm{Flink}$.springer. com $\% 252$ Farticle $\% 252 \mathrm{~F} 10.1007 \% 252 \mathrm{FBF} 02809652 * \sim \mathrm{hma}-$ $\mathrm{c}=1614 \mathrm{a} 7 \mathrm{bbc} 57710 \mathrm{bff} 5 \mathrm{fc} 82 \mathrm{f} 6 \mathrm{f} 8 \mathrm{a} 4654620 \mathrm{bfcb} 923 \mathrm{dfdc} 197405 \mathrm{c} 9 \mathrm{f}$ $58 \mathrm{c} 7 \mathrm{~b} 7 \mathrm{~d} 3 \mathrm{ee}$.

PORTELA, R.C.Q.; SANTOS, F.A.M. Caracterização dos estádios ontogenéticos de três espécies de palmeiras: uma proposta de padronização para estudos de dinâmica populacional. Revista Brasileira de Botânica, v.34, n.4, p.523-535, 2011. http://www. scielo.br/pdf/rbb/v34n4/v34n4a06.pdf

QUEIROZ, M.S.M.; BIANCO, R. Morfologia e desenvolvimento germinativo de Oenocarpus bacaba Mart. (Arecaceae) da Amazônia Ocidental. Revista Árvore, v.33, n.6, p.1037-1042, 2009. http://www. scielo.br/pdf/rarv/v33n6/a06v33n6.pdf

RANAL, M.A.; SANTANA, D.G. How and why to measure the germination process? Revista Brasileira de Botânica, v.29, n.1, p.1-11, 2006. http://www.scielo.br/scielo.php?script=sci arttext\&pid=S0100-84042006000100002

RODRIGUES, J.K.; MENDONÇA, M.S.; GENTIL, D.F.O. Efeito da temperatura, extração e embebição de sementes na germinação de Bactris maraja Mart. (Arecaceae). Revista Árvore, v.38, n.5, p.857865, 2014. http://www.scielo.br/pdf/rarv/v38n5/v38n5a10.pdf

SCHLINDWEIN, G.; SCHLINDWEIN, C.C.D.; TONIETTO, A.; DILLENBURG, L.R. Alleviation of seed dormancy in Butia odorata palm tree using drying and most-warm stratification. Seed Science \& Technology, v.41, n.1, p.16-26, 2013. http://www.ingentaconnect.com/ contentone/ista/sst/2013/00000041/00000001/art00002?crawler=true

SILVA, F.A.S.; AZEVEDO, C.A.V. The Assistat software version 7.7 and its use in the analysis of experimental data. African Journal of Agricultural Research, v.11, n.39, p.3733-3740, 2016. http://www.academicjournals.org/journal/AJAR/article-full-textpdf $/ 5 \mathrm{E} 8596460818$

SILVA, R.S.; RIBEIRO, L.M.; MERCADANTE-SIMÕES, M.O.; NUNES, Y.R.F.; LOPES, P.S.N. Seed structure and germination in buriti (Mauritia flexuosa), the Swamp palm. Flora, v.209, n.11, p.674-685, 2014. http://ac.els-cdn.com/S0367253014001212/1s $2.0-\mathrm{S} 0367253014001212$-main.pdf? tid=359208a8 22b9-11 e6-b990-00000a ab0f01\&acdnat $=1464209134$ c10df26277c164190336cbbf8a17a8a2 